Creative Commons User License: CC BY-NC-ND

Abstracted by: EBSCOhost, Electronic Journals Service (EJS),

Google Scholar, Journal Seek, Scientific Commons,

Food and Agricultural Organization (FAO), CABI and Scopus

http://eoi.citefactor.org/10.11226/v26i1
Journal of Agricultural Extension

Vol. 26 (1) January, 2022

ISSN(e): 24086851; ISSN(Print); 1119944X

http://journal.aesonnigeria.org

http://www.ajol.info/index.php/jae

Email: editorinchief@aesonnigeria.org

\title{
Assessment of Aquaculture Development Programmes in Nigeria
}

https://dx.doi.org/10.4314/jae.v26i1.2

\section{ISSA, Fadlullah Olayiwola}

National Agricultural Extension and Research Liaison Services,

Ahmadu Bello University, Zaria, Nigeria

Corresponding: issafola@gmail.com +2348033339312

\section{Aderinoye-AbdulWahab, Sidiqat}

Department of Agricultural Extension and Rural Development,

University of Ilorin, Ilorin, Nigeria

sidiay@yahoo.com +2348033594496

\section{Kagbu, Joyce Hauwa}

National Agricultural Extension and Research Liaison Services,

Ahmadu Bello University, Zaria, Nigeria

jkagbu@gmail.com +2348133344843

\section{Adisa, Rahmatallahi Adewunmi}

Department of Vocational and Technical Education,

Ahmadu Bello University, Zaria, Nigeria

rahamatallahiadewunmiadisa@gmail.com +2348146428281

\begin{abstract}
This paper assessed the various aquaculture development programmes of succeeding Nigerian Government. It particularly focused on the Fish Seed Multiplication Project (FSMP) and the pilot Fish Farm Project (PFFP); drawing lessons from their implementation. Literature review was carried out using reports of Federal Ministry of Agriculture as well as agricultural institutions for this analysis. Poor growth rate in fishery output as well as unavailability and inadequate access to modern fish-farming technologies was found to be the major challenges confronting the Nigerian aquaculture development. The paper concludes that despite some noteworthy efforts of government interventions in the fisheries sub-sector of the Nigeria economy; the growth rates of fishery output have been relatively low as manifested in the large importation of fish over the years. It recommends a proper exploitation of the aquaculture system by ensuring fish-farmers' access to modern fish-farming technologies through policy instrument.
\end{abstract}

Keywords: Fisheries, Aquaculture, Modern technology

\section{Introduction}

Aquaculture, to which fish farming is categorized is the commercial rearing of fish in settings where the basic means of production can be managed within their respective limits and where producers strive for optimal economic results (Tunde, Kuton, Oladipo \& Olasunkanmi, 2015). It is the cultivation of aquatic resources (freshwater and saltwater populations); aquatic organisms that could be reared include fish, insects, bivalves and pearls, mollusks, crustaceans, and aquatic plants, 
Creative Commons User License: CC BY-NC-ND

Abstracted by: EBSCOhost, Electronic Journals Service (EJS), Google Scholar, Journal Seek, Scientific Commons,

Food and Agricultural Organization (FAO), CABI and Scopus
Journal of Agricultural Extension

Vol. 26 (1) January, 2022

ISSN(e): 24086851; ISSN(Print); 1119944X

http://journal.aesonnigeria.org

http://www.ajol.info/index.php/jae

Email: editorinchief@aesonnigeria.org

while the controlled environments include ponds, cages, pens, and raceways (Tunde et al., 2015). Most of these aquatic organisms are consumed by man to meet their demand for high quality animal protein. However, at present, species such as tilapia, carp, mudfish and catfish are the only cultured fishery operation in Nigeria.

Aquaculture is growing swiftly throughout the world and it has the prospective for the provision of valuable protein for human consumption. In Nigeria economy, as in most African countries, aquaculture plays a significant role in employment creation and income generation (Mulokozi et al., 2020). This is mostly true of the socioeconomically weaker communities of fishermen who depend on the sale of their yields for livelihood. Despite the importance of aquaculture as being the fastest growing food producing sector, its contribution to Nigeria's total fish production is of little importance.

The current fish demand consumption in Nigeria stands at 1.4 million metric tons (Onyekuru, Ihemezie \& Chima, 2019), to satisfy the dietary requirement of its citizens but the total aggregate domestic fish supply from all sources (capture and culture fisheries) is less than 0.7 million metric tons per annum. Nigeria has to import about 0.7 million metric tons of fish valued at about $\$ 500$ million annually to augment the shortfall. Increasing the aquaculture production is clearly needed to meet this demand but despite this, demand for fish consumption exceeded the supply thereby making Nigeria one of the major importers of fish. This massive importation of frozen fish in the country has ranked Nigeria the largest importer of frozen fish in Africa (Federal Ministry of Agriculture and Rural Development (FMARD), 2012).

In 2010 for instance, the projected population in millions, fish demanded in million tons and fish supplied in million tons were $151.21,1.15$ and 0.93 respectively; in 2011 , the statistics rose to $155.50,1.18$ and 0.96 ; in 2012, the statistics rose to 159.90, 1.22 and 1.00; the statistics rose to $164.40,1.25$ and 1.04 in 2013; in 2014, the statistics rose to $169.10,1.29$ and 1.08 ; in the year 2015, the population was projected at 173.90 million, fish demanded was 1.32 million tons and the estimated fish supplied was 1.15 million tons; in 2016, the statistics rose to $178.80,1.36$ and 1.16 respectively; the projected statistics respectively rose to $183.30,1.39$ and 1.20 in 2017; the statistics rose to $189.00,1.44$ and 1.24 in 2018; in 2019, the statistics respectively rose to $194.40,1.48$ and 1.28 and the statistics rose to $199.90,1.52$ and 1.38 respectively in 2020 (Food and Agriculture Organization (FAO), 2000, cited in Amosu et al, 2017). The gap between the quantity of fish demanded and the quantity supplied that is, the shortfall in million tons increased all through and the fish supplied throughout these years came largely from domestic fish production. Production from industrial operations is usually limited, portraying the underdeveloped nature of the fishery sub-sector of the Nigerian economy when compared with operations in the more fishery-developed countries, according to FAO records $(2014,2018)$.

Due to global population expansion, demand for high quality animal protein, especially from aquatic sources is rising. The importance of the fisheries sector to 
Creative Commons User License: CC BY-NC-ND

Abstracted by: EBSCOhost, Electronic Journals Service (EJS), Google Scholar, Journal Seek, Scientific Commons,

Food and Agricultural Organization (FAO), CABI and Scopus
Journal of Agricultural Extension

Vol. 26 (1) January, 2022

ISSN(e): 24086851; ISSN(Print); 1119944X

http://journal.aesonnigeria.org

http://www.ajol.info/index.php/iae

Email: editorinchief@aesonnigeria.org

the Nigerian economy, as well as the benefits that Nigerians gain from fish and other fish products, resulted in high consumption and, as a result, increased demand for fisheries goods (Olalekan \& Wahab, 2018). Despite a local production of roughly 800,000 metric tons, Nigeria still has about 1.3 million metric tons to cover, with annual national fish demand of around 2.1 million metric tons (Akinsorotan et al, 2019). It is estimated that Nigeria spends over 288 billion naira on annual fish importation (CBN, 2017), while the present importation rate is over 750,000 . This implies that, with importation of more than 750,000 metric tons of fish, more than USD 600 million are spent in hard currency and thousands of jobs are exported (United States Agency for International Development (USAID), 2010; Federal Ministry of Agriculture and Rural Development (FMARD), 2016; United State Development Agency (USDA), 2016; Respikius, Ahmad, Lamtane, and Mtui, 2020).

The incessant importation of fish denotes a great loss of foreign exchange earnings to Nigeria, there is no doubt that economic growth is necessary for sustained development. There are many constraints militating against the development of aquaculture to meet the global food security and economic growth. FMARD (2016) asserted that the major value chain constraints in the aquaculture are low productivity of fish breeds in aquaculture and low production due to lack of inputs. In line with this, Oluwatayo and Adedeji, (2018) stated that fish farming as an industry is generally faced with some challenges which include insufficient supply of fishing inputs (fingerlings and feed), inflation of trawling operations, insufficient production of cultivable fish species fingerlings and poor availability of cost-effective feed for fish culture among others. Fish seeds are essential for successful operations of fish farms and many fish farms have been abandoned in the country for lack of fish seed. It is observed that, no less than $60 \%$ of all fish seed supply in Nigeria was from the wild (Ozigbo, Anyadike, Adegbite, and Kolawole, 2014; Digun-Aweto and Oladele, 2017; Adeleke, Robertson-Andersson, Moodley \& Taylor, 2021).

Aquaculture production in Nigeria rose in tons from $0.93 \times 10^{6}$ in 2010 to $1.12 \times 10^{6}$ in 2015 with a further increase to $1.32 \times 10^{6}$ in 2020; the projected demand for fish in Nigeria for this year, 2021 was $1.56 \times 10^{6}$ tons with a projected population of 205.60 $\times 10^{6}$ of people and a production level projected at $1.36 \times 10^{6}$ tons with a projected shortfall of $0.20 \times 10^{6}$ tons which needs to be filled (FAO, 2000, cited in Amosu et al, 2017). Aquaculture as a business venture can enhance development by improving family income, providing employment opportunities and increase food security (Ataguba et al., 2013). Among the four major fish supplies sources in Nigeria, aquaculture still remained the poorest contributor (FMARD, 2012). Supplies from importation, inland and coastal artisanal fishery, and industrial trawl fishery surpass that from aquaculture. These necessitated a deliberate attempt by the Government to develop aquaculture in Nigeria.

The promotion of aquaculture particularly, fish farming had always been a major policy initiative of succeeding Nigerian Governments. This is in line with actions in many other countries of the world and the current belief that the time will soon come when farming in fish ponds and tanks as well as the edges of the sea will be used to 
solve the protein and hunger problems of the world's growing population. Major policy thrust of the government include to enhance fish breeding; Policy to make fishery/aquaculture inputs available by promoting hatchery development, Standardization of hatchery and fish breeding processes (FMARD, 2016).

Since the 1980s, the Government of Nigeria has paid considerable attention to aquaculture. In this regard, two projects have been implemented to develop aquaculture in the country: Fish Seed Multiplication Project (FSMP) and Pilot Fish Farm Project (PFFP). FSMP and PFFP were established by the Federal Department of Fisheries FDF in the last stage of aquaculture development between $1980-1992$.

These programmes were set up for prospective fish farmers to replicate so as to produce more fish for the people. Accessibility to fish seeds in adequate quantity is one of the most important factors for a sustainable and profitable fish farming. A proper assessment of these programmes has been difficult to come by. Hence, the need for this study with the main objective to assess the aquaculture development programmes in Nigeria. Specific objectives are to:

i. access the Fish Seed Multiplication Project (FSMP) and the Pilot Fish Farm Project (PFFP),

ii. draw lesson from implementation of FSMP and PFFP, and

iii. identify the challenges confronting the Nigerian aquaculture development.

\section{Methodology:}

Desk review of literature including policy documents of FGN and FMARD (and specifically Federal Department of Fisheries) was utilized for this study.

\section{Fish Seed Multiplication Project}

The period between 1975 - 1980 marked the Third National Development Plan in which low priority was accorded to aquaculture. The result led to the commissioning of a consultancy group by the Federal Department of Fisheries. The group, that is, the Asiaphil Fisheries Corporation (AFC) of Manila (Philippines) based on its recommendation accorded a higher priority to aquaculture in the Fourth Development plan between 1980 - 1987. This led to the construction of zonal seed production and training centres between $1978-1980$. This project was implemented under the care of River Basin Development Authorities (RBDAs) who were urged by the Federal Government to establish commercial fish farms and demonstrate aquaculture's economic viability (AFC, 1980). Fish Seed Multiplication Project was launched to provide the fish farmers with fingerlings to stock their ponds. To accompany these actions, aquaculture technology centres were established by Government for fish farmers in Kaduna State (Mando model fish farm) established in 1980, Oyo State (Oyo model fish farm) established in 1980, Imo State (Umuna/Okigwe model fish farm) established in 1980 and Plateau State (Panyam fish seed multiplication centre) established in 1978. Quality fish seeds are one of the vital components for the fish growth. In boosting fish seeds supply, premium consideration should be given to the small localized hatcheries. At the same time, making adequate provision of seeds locally, can be more responsive to changing 
Creative Commons User License: CC BY-NC-ND

Abstracted by: EBSCOhost, Electronic Journals Service (EJS),

Google Scholar, Journal Seek, Scientific Commons,

Food and Agricultural Organization (FAO), CABI and Scopus

http://eoi.citefactor.org/10.11226/v26i1
Journal of Agricultural Extension

Vol. 26 (1) January, 2022

ISSN(e): 24086851; ISSN(Print); 1119944X

http://journal.aesonnigeria.org

http://www.ajol.info/index.php/iae

Email: editorinchief@aesonnigeria.org

trends in demand, more economically flexible, and have lower start-up costs thereby bridging the gap of demand and supply of fish in the country.

\section{Pilot Fish Farm Projects}

Along with these fish seed multiplication farms (FSMFs), the Pilot Fish Farm Projects (PFFP) were undertaken in various locations in the country to exemplify the approaches to off-fish farming to existing and potential fish farmers. Technical development training was provided to the fish farmers in the pilot area on how to enhance their selection of fish species, preparation of ponds, use of fertilizers, use of quality feeds and fingerlings, medicine, and water more effectively in their pond management. The pilot projects were also implemented to conduct a profound diagnosis of all the significant factors challenging fish producers on the input side.

The project was implemented to assess the reasons for the short supply of the fish feeds as well as the shortage and high price of quality fingerlings. The pilot work with concerned commercial hatcheries and fingerling nurseries to recognize the areas that can be revamped. Connection to small-scale commercial fish farmers was encouraged and innovative approaches to fingerling disposition was assessed. It also identified channels to link local agro-dealers with feed and fingerling suppliers to ensure access closer to the ponds and where there are none, the pilot should assess the possibility of encouraging the establishment of one.

\section{Lessons learnt from the implementation of FSMP and the PFFP}

The foregoing discussions on FSMP and PFFP as Government interventions in the fishery sub-sector of the Nigerian economy show that, in terms of intentions, the public actions had been substantial and noteworthy. However, observations show that these interventions had not made the required impact in the sub-sector. First, records reveal that the growth rates of fishery output have been relatively low. Similarly, the excess demand situation in the sub-sector remained real as manifested in the large importation of fish and other fishery products till date.

Inadequate data about quantity of needed inputs made planning for quantity of fish seed difficult (Kinkela et al., 2019). Hence, a more consistent and up-to-date information should be gathered in order to have the right projections about the input needed for the successful operation of fish farms. Fish seeds are one of the most vital input and are indispensable for successful operation of fish farms. Therefore, feed seeds provision should be made in large quantities to ensure the availability of fishes all year round. Also, fish farmers were not adequately carried along in the planning and implementation stage of the projects. Thus, participation by small-scale fish farmers was low. Moving forward, fish farmers should be carried along at each stage of the projects and they should be mandated to form associations as this will enable easy access and mobilization of inputs. Technological and knowledge gap should be identified as this will give birth to necessary trainings and programmes needed to bridge the gap. 
Creative Commons User License: CC BY-NC-ND

Abstracted by: EBSCOhost, Electronic Journals Service (EJS),

Google Scholar, Journal Seek, Scientific Commons,

Food and Agricultural Organization (FAO), CABI and Scopus
Journal of Agricultural Extension

Vol. 26 (1) January, 2022

ISSN(e): 24086851; ISSN(Print); 1119944X

http://journal.aesonnigeria.org

http://www.ajol.info/index.php/jae

Email: editorinchief@aesonnigeria.org

\section{Challenges confronting Nigeria aquaculture development}

In Nigeria, there is high demand for fishery resources as they are known to play important roles in nutritional requirements and national development. However, the supply has been low compare to the demand. Despite the efforts of the government in implementing policies and programmes to empower fish farmers so as to get out of this problem, there is still shortage in the supply and demand for fish. A lot of challenges have been identified as being responsible for the low production in Nigeria aquaculture development. These include:

Inadequate product development: Inadequate product development from aquaculture ventures remained a major constraint to aquaculture development. Over $80 \%$ of farmed fish currently produced in the country is sold live. One of the negative consequences of this is that the farmers at times are compelled to sell at a not-too-profitable price, which may be a disincentive to expand their production base. Lack of fish fingerlings: Lack of fish fingerlings has been one of the major constraints for aquaculture development in Nigeria for the past 40 years (Aquaculture and Inland Fisheries Project (AIFP), 2005). Fish seeds are indispensable to the operations of fish farms. Thus, the federal government of Nigeria introduced the fish farm project under which pilot fish farms were established for potential fish farmers to replicate so as to produce more fish for the people. In addition, the Fish Seed Multiplication Project was designed to provide fish farmers with fingerlings with which to stock their ponds (FDF, 2007, Koge et al., 2018). However, farmers are increasingly abandoning fish farming in favour of other agricultural ventures. Some of the causes cited include poor quality of fish feed and seed and reduced profitability of fish farming (Digun-Aweto \& Oladele, 2017).

Others are poor growth rate in fishery output as well as unavailability and inadequate access to modern fish-farming technologies. Also, high cost of feeds, lack of capital, scarcity of fingerlings, lack of modern technologies, high cost of transportation, high cost of labour, lack of land, poaching, inadequate water supply, mortality of fish and poor storage facilities (FAO, 2014) pose great challenges to fishery sector. FMARD, (2011 and 2012) identified insufficient development of the fish processing, underutilization of the seafood processing capacity, as well as insufficient knowledge, technology and investment for aquaculture products for storage and transport as key constraints in aquaculture value chain.

\section{Conclusion and Recommendations}

Fish development projects namely the Fish Seed Multiplication Project (FSMP) and Pilot Fish Farm Project (PFFP) implemented by the government had little or no important in controlling these problems.

Considerable attention should be paid on processing and value-addition activities by upgrading the existing fish processing facilities and establishment of additional ones especially in high-volume production states. Training and capacity building in the preparation and packaging of the products should be facilitated. Product certification and protocol development, especially to meet export requirement standard should be handled by relevant government agencies. 
Creative Commons User License: CC BY-NC-ND

Abstracted by: EBSCOhost, Electronic Journals Service (EJS), Google Scholar, Journal Seek, Scientific Commons,

Food and Agricultural Organization (FAO), CABI and Scopus

http://eoi.citefactor.org/10.11226/v26i1
Journal of Agricultural Extension

Vol. 26 (1) January, 2022

ISSN(e): 24086851; ISSN(Print); 1119944X

http://journal.aesonnigeria.org

http://www.ajol.info/index.php/iae

Email: editorinchief@aesonnigeria.org

Fish farmers should be exposed to modern fish farming technologies to ensure proper exploitation of fish industry. Adequate support should be provided to extension agencies and input suppliers to improve and expand services and input delivery to fish farmers.

\section{References}

Adeleke, B., Robertson-Andersson, D., Moodley, G. \& Taylor, S. (2021). Aquaculture in Africa: A comparative review of Egypt, Nigeria, and Uganda Vis-À-Vis South Africa. Reviews in Fisheries Science and Aquaculture, 29(2), 167-197.

Akinsorotan, A.M., Akinsorotan, O. A., Jimoh, J. O., Adene, I.C. and Akinwowo, U. A. (2019). Offshore aquaculture practice, a potential for meeting Nigeria fish demand: A Review. Journal of Physics: Conf. Series 1299012111

Amosu, A. O., Hammed, A. M., Togunde, K. A., Joseph, O. O. and Adekoya, A. (2017). Possible aquaculture development in Nigeria: Evidence for commercial prospects. Journal of Agricultural Science and Technology, B 7 194-205

Asiaphil Fisheries Corporation. (1980). Full feasibility studies of three fish farm projects of 500 ha each in Bodo, Buguma, and Pereambir, Rivers State. Manila, Philippines.

Ataguba, G. A., Ogbe, F. G., Solomon, S. G. and Okomoda, V. T (2013). Aquaculture business management in Nigeria: Issues and considerations-A review. Proceedings of 28th Annual Conference of FISON held 25-30 ${ }^{\text {th }}$ Nov Pp 87-91

Central Bank of Nigeria (CBN). (2017). Annual Report.

Digun-Aweto, O. and Oladele, A. H. (2017). Awareness of improved hatchery management practices among fish farmers in Lagos State. AGRICULTURA TROPICA ET SUBTROPICA, 50/1, 19-25.

Digun-Aweto, O. and Oladele, A. H. (2017). Constraints to adoption of improved hatchery management practices among catfish farmers in Lagos State. Journal of Central European Agriculture, 18(4): 841-850.

Federal Ministry of Agriculture and Rural Development (FMARD), (2011). Agricultural Transformation Agenda Blue Print. Pp89.

Federal Ministry of Agriculture and Rural Development (FMARD), (2012). Aquaculture Transformation Implementation Plan

Federal Ministry of Agriculture and Rural Development (FMARD), (2016). The Agriculture Promotion Policy (2016 - 2020). Policy and Strategy Document. 59pp.

Food and Agriculture Organization (FAO), (2014). The state of world fisheries and aquaculture 2014: Opportunities and challenges. Rome: Italy. 223 pp.

Food and Agriculture Organization (FAO), (2018). The State of World Fisheries and Aquaculture 2018-Meeting the sustainable development goals. Rome, Italy. http://www.fao.org/3/i9540en/i9540en.pdf. Accessed June 23, 2015.

Kinkela, M. P., Mutiaka, B. K., Dochain, D., Rollin, X., Mafwila, J. \& Bindelle, J. (2019). Smallholders' practices of integrated agriculture aquaculture system in Periurban and rural areas in sub-Saharan Africa. Tropicultura, 37(4):1-19.

Koge, J., Opola, F., Obwanga. B., Kilelu, C., Rurangwa, E. (2018). A comparative study on aquaculture sector development in Egypt, Ghana and Nigeria: Sharing insights and drawing lessons for Kenya. In 3R Kenya Workshop Report 002. p. 22. https://library.wur.nl/WebQuery/wurpubs/fulltext/459595.

Mulokozi, D. P., Mmanda, F. P., Onyango, P., Torbjörn, L., Tamatamah, R. \& Berg, H. (2020). Rural aquaculture: Assessment of its contribution to household income and farmers' perception in selected districts, Tanzania, Aquaculture Economics and Management, DOI: 10.1080/13657305.20 20.1725687 
Olalekan, J. O. and Wahab, G. O. (2018). Marine fisheries in Nigeria: A review, marine ecology - biotic and abiotic interactions, Muhammet Türkoğlu, Umur Önal and Ali Ismen, IntechOpen, DOI: 10.5772/intechopen.75032.

Oluwatayo, I. B., and Adedeji, T. A. (2019). Comparative analysis of technical efficiency of catfish farms using different technologies in Lagos State, Nigeria: A data envelopment analysis (DEA) approach. Agric \& Food Secur 8(8).

Onyekuru, N. A., Ihemezie, E. J. \& Chima, C. C. (2019). Socio-economic and profitability analysis of catfish production: A case study of Nsukka Local Government Area of Enugu State, Nigeria. Journal of Tropical Agriculture, Food, Environment and Extension 18 (2): 51-58.

Ozigbo, E., Anyadike, C., Adegbite, O. and Kolawole, P. (2014). Review of Aquaculture Production and Management in Nigeria. American Journal of Experimental Agriculture, 4(10): 1137-1151.

Respikius, M., Ahmad, A.K., Lamtane, H. \& Mtui, H.D. (2020). Potential, challenges and opportunities for promoting integrated agri-aquaculture among vegetable growers and fish farmers in Mvomero District of Morogoro Region, Tanzania. Tanzania Journal of Agricultural Sciences, 19(2), 78-91.

Tunde, A. B., Kuton, M. P., Oladipo, A. A. and Olasunkanmi, L. H. (2015). Economic analyze of costs and return of fish farming in Saki-east Local Government Area of Oyo State, Nigeria. Journal of Aquaculture Resources Development, 6 (2):306-310.

United State Development Agency (USDA) (2016). The state and development of aquaculture in Egypt. http://www.fas.usda.gov/data/egypt-state-and-developmentaquaculture-egypt. 